\title{
Application of the Randomly Amplified Polymorphic DNA (RAPD) Markers to Analyze the Genetic Variability in Species of the Fungus Alternaria
}

\author{
Sahi J. Dhahi \\ Department of Biology \\ College of Science \\ Mosul University
}

\author{
Akeel H. Al-Assie \\ Department of Biology \\ College of Science \\ Tikrit University
}

\author{
Hadeel A. Omear \\ Department of Biology \\ College of Science \\ Tikrit University
}

(Received 22/2/2010; Accepted 20/9/2010)

\begin{abstract}
The PCR-based technique of randomly amplified polymorphic DNA (RAPD) was used to fingerprint and assess the genetic relatedness among nine species of the fungus Alternaria isolated from various crop plants showing the leaf spot disease in Mosul, Iraq. Genomic DNA of each species was extracted at a final concentration of $300-400 \mu \mathrm{g} / 2-3 \mathrm{~g}$ of wet mycelium, and at a purity of 1.6-1.8. Each DNA sample was amplified with each of 22 primers and the products were resolved electrophoretically on $1.2 \%$ agarose gel, stained with ethidium bromide and photographed under UV. One Primer failed to support amplification but the remaining $21(95.5 \%)$ primers produced a total of 112 bands (2-10 per primer) across the nine species. Of these bands, 100 (1-10 per primer ) were polymorphic. The least efficient primer was OP-H01 (1.79\%), while the most efficient one weas OP-M05 $(8.93 \%)$. Primers OP-C05, OP-E20 and OP-T20 had the lowest $(0.1 \%)$ discriminatory power while primer OP-M05 had the highest $(10 \%)$ power and identified all 9 species through unique patterns of banding. RAPD analysis fingerprinted eight of the nine isolates through marker bands with one or more of the 21 primers. Cluster analysis based on the genetic distances split the nine species into three distinct clusters with no obvious association between the pattern of clustering of the species and their host specificities.
\end{abstract}

Keywords : Alternaria, Genetic variability, RAPD , PCR

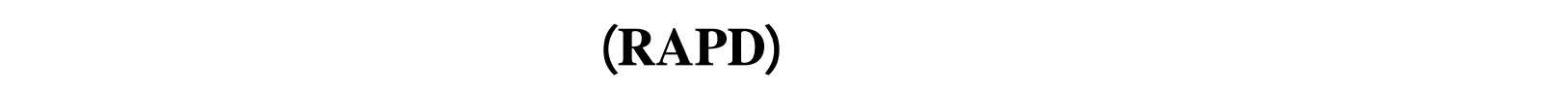

\section{Alternaria الهار}

\section{ll}

لقد جرى لمتخدلم ققنية RAPD المعتمة على تفاعل PCR لايجاد البصمة الوراثية والعلاقة الوراثية

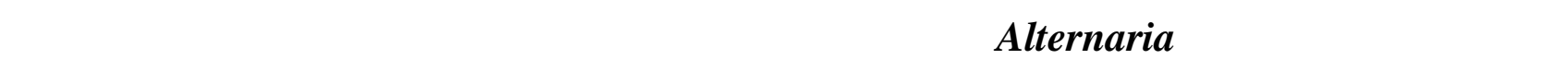

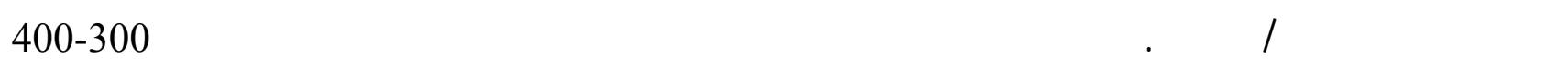


مايكروغرلم للك 2-3غرلملت من الغزل النطري الرطب وبقاوة 1.6-1.8. وجرت مضاعفة كل عيذ ة مـ ن ن

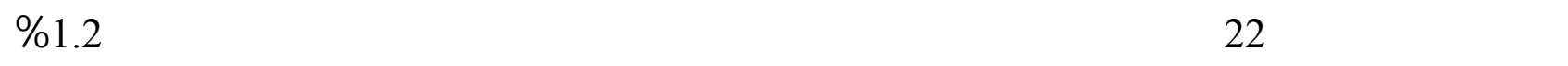

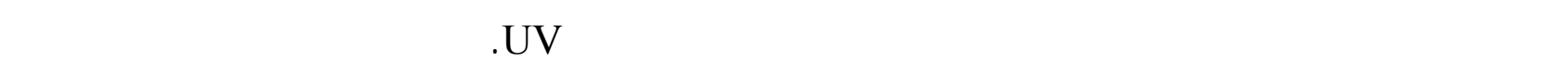

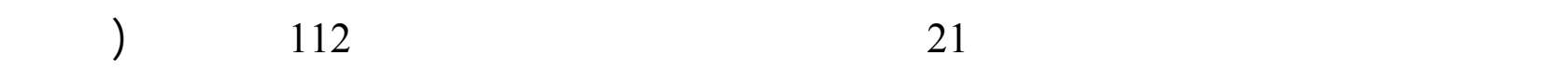

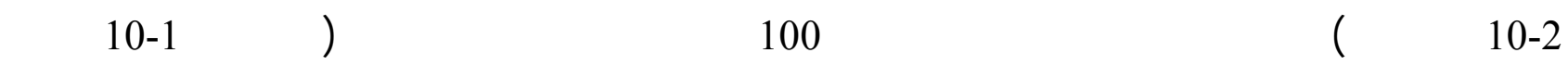

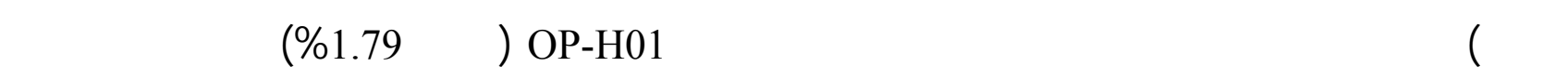

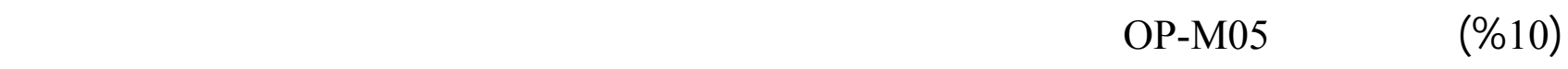

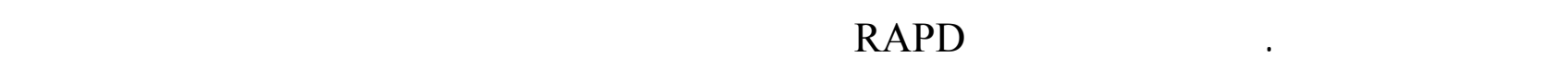

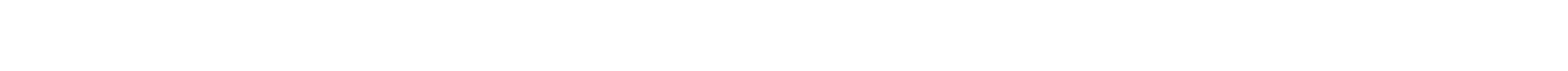

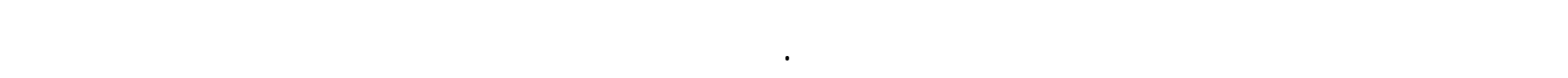

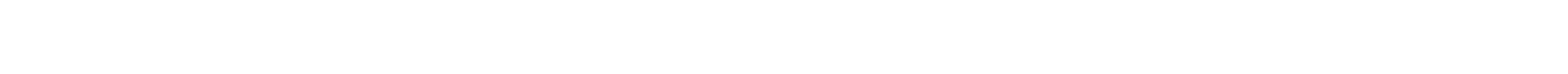
على هذه العناقيد الثلاثة وتوزيعها على المضاف الف التي جمعت منها.

\section{INTRODUCTION}

Classification or identification is, in essence, application or utilization of genetic variability to distinguish between and separate various individuals and taxa or vice versa to link and group individuals and texa. The manifestation of this variability can be phenotypic (morphological and anatomical) and hence phenetic classification (Simpson, 1961; Lawrence, 1964; Sneath and Sokal, 1973) or biochemical (e.g. natural products, isozymes) and thus the term chemotaxonomy (Smith, 1976). Both types of manifestation are removed far from the genetic material, do not express the full genetic variability, and need long experience (phenetic methods) or are very lengthy and costy (isozymes).

Advances in molecular biology and genetic engineering have provided a new class of genetic markers that allowed looking at the genetic variability at the DNA level. These were commonly called the DNA markers and the first category of them to be utilized was the restriction fragment length polymorphisms (RFLPs) (Botestien et al., 1980). The RFLPs markers were recognized by autoradiography after hybridization with suitably labeled probes. These were soon followed by other DNA markers whose recognition depended on using short oligonucleotide primers to selectively amplify the target DNA markers and visualize their electrophoretic gels by staining with a DNA-specific dye. The application of this type of DNA markers was made possible by the discovery in the early 1980s of the polymerase chain reaction (PCR) technique (Mullis et al., 1986) and ever since a variety of these PCR-based markers and their applications have been developed (Caetano-Anolle's and Gresshoff, 1997).

The randomly amplified polymorphic DNA (RAPD) markers, developed independently by Williams et al., (1990) and by Welsh and McClelland (1990), soon became one of the PCR-based DNA markers most widely used for linkage mapping and detection of relatedness between species (Rafalski, 1997; Bardakci, 2001; Tahir, 2008). The technique 
relies on using short primers $(\approx 10$ bases) with random sequences and less stringent demands for pairing that allows amplification of DNA polymorphisms randomly distributed all over the genome and giving varied patterns of banding on gels that can be used for distinction between species or linkage mapping (Williams et al., 1990).

In the present work, an attempt was made to use the RAPD technique for checking the relatedness among nine fungal species of the genus Alternaria which was earlier deduced from phenetic and numerical taxonomic methods using both phenotypic and chemical characterstics (Al-Taee, 2007).

\section{Fungal isolates}

\section{MATERIAL AND METHODS}

A total of nine species of the genus Alternaria was used in the present work. The origins and other specifications of the isolates are given in Table 1. They were kindly provided by Dr.Warka S. Al-Taee, Biology Department, College of Science, Mosul University, Iraq. They were subpopulation of a larger collection of species of this genus whose details are given in Al-Taee (2007).

Table 1: Origins of the Alternaria species used in the present wark (Al-Taee, 2007).

\begin{tabular}{|c|c|c|c|}
\hline $\begin{array}{c}\text { Numbering } \\
\text { in the } \\
\text { present } \\
\text { work }\end{array}$ & Species & $\begin{array}{c}\text { Corresponding } \\
\text { No.in Al-Taee } \\
(2007)\end{array}$ & $\begin{array}{c}\text { Source of isolation } \\
\text { (Host) } \\
\text { (Al-Taee,2007) }\end{array}$ \\
\hline 1. & Alternaria radicina & 10 & Vicia faba \\
\hline 2. & A. state & 8 & Brassica oleracea \\
\hline 3 & A. raphani & 13 & Solanum tuberosum \\
\hline 4. & A.tenuissima & 2 & Beta vulgaris var cila \\
\hline 5. & A.alternata1 & 6 & Brassica oleracea \\
\hline 6. & A.longipes & 11 & Raphanus sativus \\
\hline 7. & A.brassicae & 5 & Brassica repa \\
\hline 8. & A.alternaria2 & 15 & Beta vulgaris var \\
vulgaris
\end{tabular}

\section{Culture media and culturing the fungal isolates}

The potato sucrose agar (PSA) medium described by Dhingra and Sinclair(1983) was used. All species were subcultured on PSA plates, single spored, put on PSA slants and stored at $4^{\circ} \mathrm{C}$ until they were used. To grow mycelium, PS broth (PSA lacking agar) was prepared and distributed into $200 \mathrm{ml}$ flasks $(50 \mathrm{ml}$ each). To induce vigorous mycelial growth and substitute for agitation (as no shaking incubator was available at the time ), $5 \mathrm{gs}$ of yeast extract/L were included in the PS broth before distribution and autoclaving. After cooling, each flask was inoculated with a single colony grown for three days on a PSA plate. Cultures were incubated statically for $7-10$ days at $24^{\circ} \mathrm{C}$. 


\section{DNA extraction}

DNA was extracted from the mycelia using the cetyltrimethyl ammonium bromide (CTAB) method described by Weigand et al., (1993). The concentration and purity of the extracted genomic DNA were determined spectrophotometrically as described by Sambrook et al., (1989). Readings were taken at $260 \mathrm{~nm}$ and $280 \mathrm{~nm}$. The reading at $260 \mathrm{~nm}$ allows calculation of the concentration of DNA in the sample. An OD of 1 corresponds to approximately $50 \mu \mathrm{g} / \mathrm{ml}$ for double-stranded DNA. Therefore, if a 100 fold diluted sample of the extract was used the concentration of the original sample will be $(\mu \mathrm{g} / \mathrm{ml})=\mathrm{OD}$ at 260 $\mathrm{nm} \times$ dilution factor $(100) \times 50(\mu \mathrm{g} / \mathrm{ml})$.

The ratio between the readings at $260 \mathrm{~nm}$ and $280 \mathrm{~nm}$ (OD $260 \mathrm{~nm} /$ OD $280 \mathrm{~nm}$ ) provides an estimate for the purity of the DNA. Pure preparations of DNA have OD $260 \mathrm{~nm}$ / OD $280 \mathrm{~nm}$ of 1.8 .

\section{Determination of the molecular size of the DNA fragments (bands)}

The molecular size the genomic DNA samples was determined by running them on a $1 \%$ agarose gel and comparing with undigested $\lambda$ DNA sample (Promega, USA) run in a separate lane on the same gel. The molecular sizes of the DNA fragments amplified by the PCR with each primer were determined by calibration to a curve made for a $\lambda$ DNA sample simultaneously digested with EcoRI and HindIII restriction enzymes (Promega, USA) (Sambrook et al. , 1989). The digest contained fragments with known molecular sizes and was run in a separate lane on a $1.2 \%$ agarose gel having a control lane and 9 other lanes for the 9 PCR products of the fungal species with each primer. The $\lambda$ DNA digest produced 12 DNA size markers. They were, from well downwards ; 21226 , 5148 , 4973 , 4268 , 3530 , $2027,1904,1584,1375,974,831$, and 564 bp.

\section{The RAPD amplification conditions}

The RAPD reactions were done for the nine fungal genomic DNA samples using 22 primers whose numbers and sequences are shown in Table 2 . These are a random set of a larger standard set of 520 random primers (OP-A01 - OP-Z20) commercially available (Operon Technology, USA). All of these primers are 10-meres oligonucleotides with 60-70 percent GC content and are used to all types of organisms irrespective of the GC content of the DNA amplified. As these primers are randomly designed and not complementary to specific sequences in the amplifies genome, the high GC content is essential for the nonstringent initial annealing of the primers to their target genomic DNA (Newton and Graham, 1997; Rafalski, 1997). If the RAPD markers are used to detect polymorphism and genetic relationships, as in the present work, a large number of the primers is recommended as many primers could produce monomorphic bands across the species tested (Rafalski, 1997 ; Tahir, 2008).

The reaction conditions were as described by Williams et al., (1990). The concentration of the genomic DNA in all samples was adjusted with TE buffer to be $25-50 \mathrm{ng} / \mu \ell$. Amplification reactions were performed in volumes of $25 \mu \ell$ containing the components shown in Table 3. 
Application of the Randomly Amplified.....

Table 2: Numbers and sequences of the RAPD primers used

\begin{tabular}{|c|c|}
\hline Primer & Sequence \\
\hline OP-C05 & ${ }^{5} \mathrm{GATGACCGCC}^{3}$ \\
\hline OP-E20 & ${ }^{5} \mathrm{AACGGTGACC}{ }^{3}$ \\
\hline OP-H01 & ${ }^{5} \mathrm{GGTCGGAGAA}^{3}$ \\
\hline OP-I02 & 'GGAGGAGAGG $^{3}$ \\
\hline OP-K01 & ${ }^{5}$ CATTCGAGCC ${ }^{3}$ \\
\hline OP-L05 & ${ }^{5}$ ACGCAGGCAC ${ }^{3}$ \\
\hline OP-L20 & ${ }^{5}$ TGGTGGACCA ${ }^{3}$ \\
\hline OP-M05 & ${ }^{5}$ GGGAACGTGT $^{3}$ \\
\hline OP-M06 & ${ }^{5}$ CTGGGCAACT ${ }^{3}$ \\
\hline OP-M14 & ${ }^{5}$ AGGGTCGTTC ${ }^{3}$ \\
\hline OP-M20 & ${ }^{5^{\prime}} \mathrm{AGGTCTTGGG}{ }^{3}$ \\
\hline OP-N16 & ${ }^{51} \mathrm{AAGCGACCTG}{ }^{3}$ \\
\hline Op-P04 & ${ }^{5}$ GTGTCTCAGG ${ }^{3}$ \\
\hline OP-R06 & ${ }^{5}$ GTCTACGGCA ${ }^{3}$ \\
\hline OP-R12 & ${ }^{5^{\prime}} \mathrm{ACAGGTGGT}{ }^{3}$ \\
\hline OP-R14 & ${ }^{5}$ CAGGATTCCC ${ }^{3}$ \\
\hline OP-T19 & ${ }^{5}$ GTCCGTATGG ${ }^{3}$ \\
\hline OP-T20 & ${ }^{5}$ GACCAATGCC ${ }^{3}$ \\
\hline $\mathrm{OP}-\mathrm{V} 02$ & ${ }^{5}$ AGTCACTCCC ${ }^{3}$ \\
\hline OP-V09 & ${ }^{5}$ TGTACCCGTC ${ }^{3 !}$ \\
\hline OP-V14 & ${ }^{5}$ AGATCCCGCC ${ }^{3}$ \\
\hline OP-V19 & ${ }^{5} \mathrm{GGGTGTGCAG}^{3}$ \\
\hline
\end{tabular}

Table 3: Compositions of the PCR reaction master mix.

\begin{tabular}{|c|c|c|c|}
\hline Reagent* & $\begin{array}{c}\text { Final } \\
\text { concentration }\end{array}$ & $\begin{array}{c}\text { Amount per one } \\
\text { reaction }(\mu \ell)\end{array}$ & $\begin{array}{c}\text { Master mix }(\mathrm{x} 10) \\
(\mu \ell)\end{array}$ \\
\hline PCR buffer $(\mathrm{x} 10)$ & $1 \mathrm{x}$ & 2.5 & 25 \\
\hline $\mathrm{dNTPs}$ & $200 \mu \mathrm{m}$ & 2.5 & 25 \\
\hline Primer & 10 picomole & 2 & 20 \\
\hline $\mathrm{dH}_{2} \mathrm{O}$ & - & 15.8 & 258 \\
\hline $\begin{array}{c}\text { Taq polymerase } \\
(5 \mathrm{U} / \mu \ell)\end{array}$ & $1 \mathrm{U}$. & 0.2 & 230 \\
\hline \multicolumn{2}{|c|}{ Total } \\
\hline $\begin{array}{c}\text { An aliquot of } 23 \mu \ell \text { from the master mix was pipetted into each of 9 thin-walled } \\
\text { eppendorf tubes }\end{array}$ \\
\hline $\begin{array}{c}\text { Genomic DNA } \\
\text { sample }\end{array}$ & $25-50 \mathrm{ng} / \mathrm{ml}$ & 25 \\
\hline Final volume & \multicolumn{3}{|c}{} \\
\hline
\end{tabular}

* The reagents should be added in the order listed in the table. 
Due to the small amounts of reagents used per individual reactions and to ensure accuracy, a master reaction mixture enough for 10 reactions (the nine genomic DNAs plus one spare reaction) was prepared as in Table 3. Amplification was performed in a Hybrid (USA) DNA Thermal Cycler programmed for a period of 4 minutes at $94^{\circ} \mathrm{C}$ for initial strand separation followed by 40 cycles of $30 \mathrm{sec}$ at $94^{\circ} \mathrm{C}, 45 \mathrm{sec}$ at $36^{\circ} \mathrm{C}$ to allow primer annealing, $45 \mathrm{sec}$ at $72^{\circ} \mathrm{C}$ for primer extension and a final period of 7 minutes at $72^{\circ} \mathrm{C}$ for extension completion. Amplification products were analyzed by electrophoresis in $1.2 \%$ agarose, detected by staining with ethidium bromide, and photographed under UV.

\section{Analysis of the amplified DNA polymorphisms}

The banding patterns on the gels were transformed into tables of binary characters where the appearance of a band was given the number one (1) while the absence of the band was denoted by zero (0). The tables were used to (i) determine the total number of bands together with their molecular weights that were produced by a primer across all isolates starting from the lowest weight (bottom of the gel) to the highest weight (top of the gel) (Cao et al., 1999) (ii) to determine the monomorphic or common bands (appearing in all isolates) and polymorphic bands (appearing in some isolates only) amplified by a primer (iii) to determine the \% efficiency of a primer. This was estimated as a percentage of the total number of bands amplified by the primer out of the total number of bands amplified by all primers across all species. This represents the availability of sequences complementary to the primer in the genome (iv) to determine the discriminatory power of the primer (Grundman et al., 1995). This is a percentage of the polymorphic bands amplified by a primer out of the total number of polymorphic bands given by all primers in all isolates (v) to determine the number of patterns of banding produced by a primer across all isolates amplified by this primer. This will be used to identify an isolate : (a) Through the presence of a unique pattern of banding (number of bands and their molecular weights) that distinguishes it from other isolates amplified by the same primer (Zaid et al., 1999). (b) To fingerprint it through the absence of a common band that is present in all other isolates amplified by the primer. Or, through a unique or specific band (s) or marker (s) present in this isolate and not in other isolates when amplified by the same primer. This specific marker or band can be useful in two ways ; first it can be scraped from the gel and reamplified with the same primer but in the presence of a labeled dNTP to produce labeled probes that can be used for hybridization and detection of any Restriction Fragment Length Polymorphism (RFLP) that can be produced by any restriction enzyme within the original specific RAPD fragment (band) (Williams et al., 1990). Second, the specific RAPD bands or markers can be sequenced and used to prepare primers that are specific for this marker that can be used to specifically identify the isolate producing these specific markers (Alaaraji, 2003). (vi) The tables of binary characters can be used to determine the genetic distances between the various species. To this end the tables of binary character were fed into the computer program Similarity for Qualitative Data (SIMQUAL). 
Calculation of the genetic distance (GD) between isolate (i) and isolate (j) is based on the equation of Nei and Li (1979) where

Where

$$
\mathrm{GD}=1-[2 * \mathrm{Nij} /(\mathrm{Ni}+\mathrm{Nj})]
$$

$\mathrm{Nij}=$ number of bands common to both the $\mathrm{i}$ and the $\mathrm{j}$ isolates .

$\mathrm{Ni}=$ Total number of bands appearing in $\mathrm{i}$.

$\mathrm{Nj}=$ Total number of bands appearing in $\mathrm{j}$.

The resulting matrix of the genetic distances is used to draw the clustering of the isolates within a dendrogram depending on the genetic closeness of members of each cluster. This was achieved by feeding the data of the matrix in to the Sequential Agglomerative Hierarchical and Nested Clustering (Sneath and Sokal, 1973) which depends on the Unweighted Pair-Group Method with Arithmetic Averages (UPGMA).

All these were with the statistical package : Numerical Taxonomy and Multivariate Analysis system NTSYS-PC version 1.80 (Rohlf, 1993).

\section{RESULT AND DISCUSSION}

The method of Weigand et al., (1995) for extracting DNA from the fungal mycelia proved sufficient in the present work where genomic DNA was obtained at a concentration of 300-500 $\mu \mathrm{g} / \mu \ell$ for each 2-3 g of mycelium sample. The purity of the DNA preparations (as determined by spectrophotometer reading at $260 \mathrm{~nm}$ and $280 \mathrm{~nm}$ ) ranged between 1.8-2.0. The average size of the genomic DNA as deduced from electrophoresis on $1.2 \%$ agarose gel was about $50 \mathrm{~kb}$ as judged from comparison with an undigested $\lambda$ DNA sample run on the same gel (Fig. 1.a). 


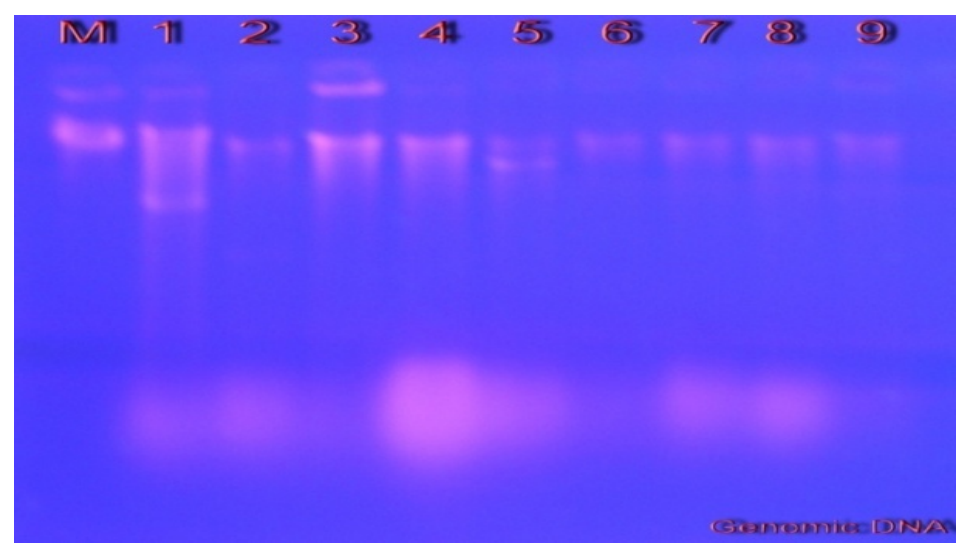

a

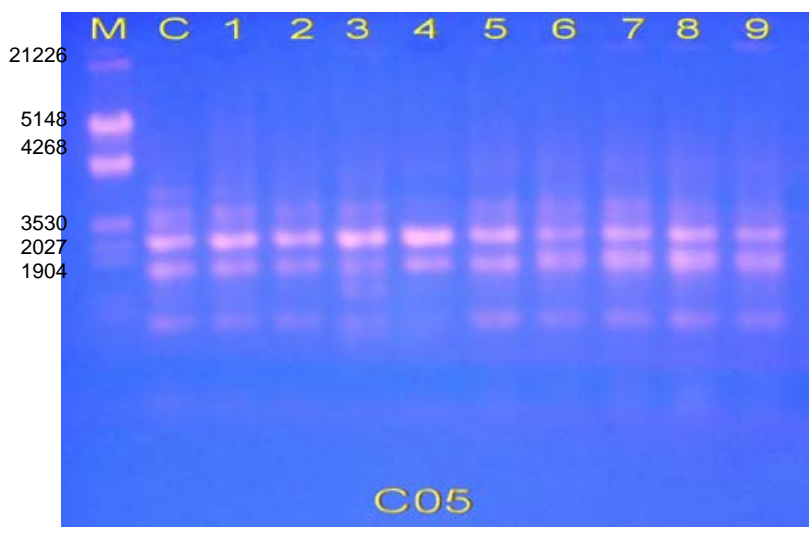

$\mathrm{b}$

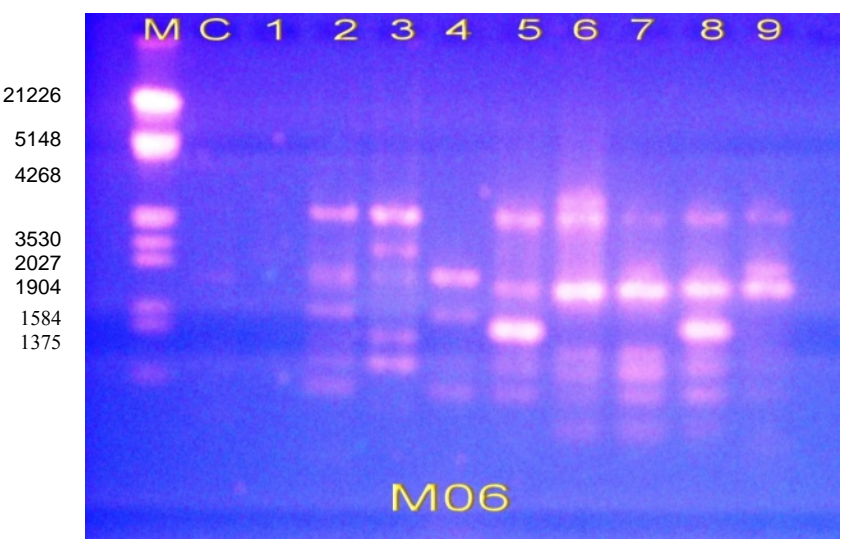

d
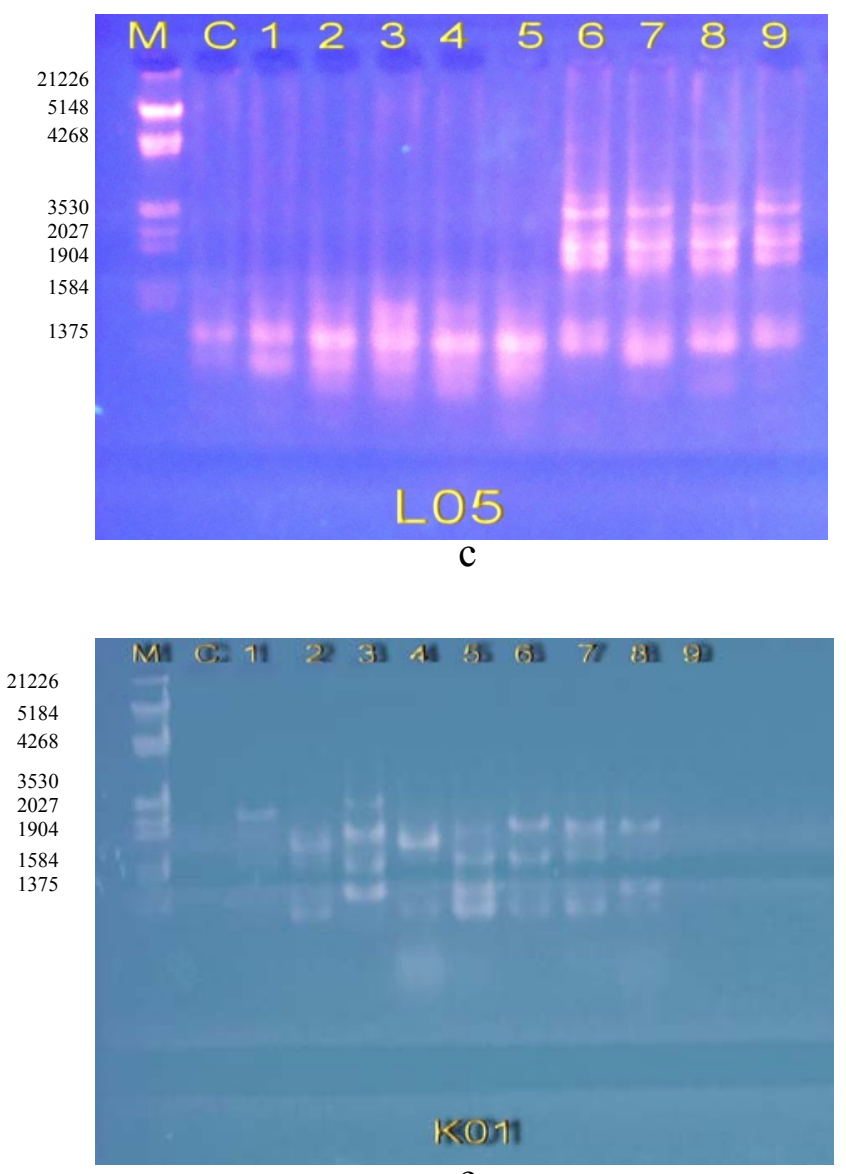

e

Fig. 1: Electrophoresis gels( $1 \%$ agarose) of the genomic DNA (a) and (1.2\% agarose) of its PCR products with four representative RAPD (OP-C05, OP-L05,OP-M06 and OP-K01) primers (b-e). Lane M (marker) contains intact $\lambda$ DNA in (a) and $\lambda$ DNA digested with EcoRI and HindIII (fragment sizes in bp are shown) in b-e. Lane C (control) contains the master mix without genomic DNA. Other lanes contain genomic (a) and the PCR products (b-e) with genomic DNA from 1-A.radicina, 2-A.state, 3-A.raphani, 4-A.tenuissima , 5-A.alternata 1, 6-A.longipes , 7-A.brassicae, 8-A.alternata 2, 9-A.cheiranthi ; monomorphic bands with OP-C05; two monomorphic groups with OP-L05 and polymorphic bands with OP-M06 and OP-K01. 
The concentration of genomic DNA was 25-50 ng/reaction. The condition for RAPD reaction set by Williams et al., (1993) were quite satisfactory and all but one primer gave amplified fragments in the present work. The single primer that gave no amplified fragments, despite several repeats, was OP-V02. This might be attributed to lack of complementary sequences to this primer among the genomic DNA from the 9 fungal species (Devos and Gale, 1992).

The remaining $21(95.5 \%)$ primers all gave amplified bands (representative of these PCR products are shown in Fig1). Primers OP-C05 (Fig1.b), OP-E20 and OP-T20 all gave monomorphic bands except one polymorphic band per each primer (Table 4). Primers OPL05 (Fig1.c) and OP-N16, on the other hand, each split the PCR products of the nine fungal species in to two monomorphic groups. It's to be noticed in (Fig1.a and b) that there are spillages, during loading, of the PCR products from lane 1 to the control (lane c) as can be judged from the identical patterns of banding in lane 1 and lane $\mathrm{c}$ in both cases. The remaining 16 primers gave variable patterns of polymorphic and monomorphic bandings across the nine spices (e.g. Fig. 1.d and e).

All in all, the 21 primers gave amplified fragments totalling at 112 and ranging between 2 (in OP-H01) and 10 (in OP-M05) across the 9 fungal species with a corresponding primer efficiency of amplification ranging between $1.79 \%(\mathrm{OP}-\mathrm{H} 01)$ and $8.93 \%$ (OP-M05) (Table 4). High efficiency of a primer is indicative of a large area of the genome that complements and allows base pairing between the primer and the genomic DNA (Karp and Edwards, 1997). Moreover it has been suggested (Fristch et al., 1993) that high efficiency positively correlates with the high GC content of the primer. This suggestion, however, is not supported by results of the present work as primer OPC05(with70\% GC) and primer OP-E20 (with 60\% GC ) have equivalent efficiencies (3.57\% each) (Table 4). 
Table 4: Fragments amplified by the 21 primers in the 9 fungal species and the $\%$ efficiency of amplification and discriminatory power of each primer.

\begin{tabular}{|c|c|c|c|c|c|}
\hline \multirow[t]{2}{*}{ primer } & \multirow[t]{2}{*}{ Sequence } & \multicolumn{2}{|c|}{$\begin{array}{c}\text { No. of bands amplified in } \\
\text { all } 9 \text { species }\end{array}$} & \multirow{2}{*}{$\begin{array}{c}\text { Primer } \\
\text { efficiency } \\
(\%)\end{array}$} & \multirow{2}{*}{$\begin{array}{c}\text { Primer } \\
\text { discriminatory } \\
\text { power }(\%)\end{array}$} \\
\hline & & Total & polymorphic & & \\
\hline OP-C05 & ${ }^{5} \mathrm{GATGACCGCC}^{3^{\prime}}$ & 4 & 1 & 3.57 & 1.0 \\
\hline OP-E20 & ${ }^{5^{\prime}}$ AACGGTGACC ${ }^{3^{\prime}}$ & 4 & 1 & 3.57 & 1.0 \\
\hline OP-H01 & ${ }^{5^{\prime}}$ GGTCGGAGAA ${ }^{3}$ & 2 & 2 & 1.79 & 2.0 \\
\hline OP-I02 & ${ }^{\prime \prime}$ GGAGGAGAGG $^{3}$ & 6 & 6 & 5.36 & 6.0 \\
\hline OP-K01 & ${ }^{5} \mathrm{CATTCGAGCC}^{3^{\prime}}$ & 8 & 8 & 7.14 & 8.0 \\
\hline OP-L05 & ${ }^{5^{\prime}} \mathrm{ACGCAGGCAC}{ }^{3^{\prime}}$ & 7 & 6 & 6.25 & 6.0 \\
\hline OP-L20 & $5^{\prime}$ TGGTGGACCA $^{3^{\prime}}$ & 9 & 9 & 8.04 & 9.0 \\
\hline OP-M05 & ${ }^{5^{\prime}}$ GGGAACGTGT $^{3^{\prime}}$ & 10 & 10 & 8.93 & 10.0 \\
\hline OP-M06 & ${ }^{5^{\prime}} \mathrm{CTGGGCAACT}^{3^{\prime}}$ & 9 & 9 & 8.04 & 9.0 \\
\hline OP-M14 & ${ }^{5^{\prime}}$ AGGGTCGTTC ${ }^{3^{\prime}}$ & 7 & 7 & 6.25 & 7.0 \\
\hline OP-M20 & ${ }^{5^{\prime}}$ AGGTCTTGGG $^{3{ }^{\prime}}$ & 3 & 3 & 2.68 & 3.0 \\
\hline OP-N16 & ${ }^{5^{\prime}} \mathrm{AAGCGACCTG}^{3^{\prime}}$ & 6 & 6 & 5.36 & 6.0 \\
\hline Op-P04 & ${ }^{5^{\prime}}$ GTGTCTCAGG $^{3^{\prime}}$ & 5 & 5 & 4.46 & 5.0 \\
\hline OP-R06 & ${ }^{{ }^{\prime}} \mathrm{GTCTACGGCA}^{3{ }^{\prime}}$ & 3 & 3 & 2.68 & 3.0 \\
\hline OP-R12 & ${ }^{5^{\prime}} \mathrm{ACAGGTGCGT}^{3^{\prime}}$ & 5 & 5 & 4.46 & 5.0 \\
\hline OP-R14 & ${ }^{5^{\prime}} \mathrm{CAGGATTCCC}{ }^{3^{\prime}}$ & 4 & 3 & 3.57 & 3.0 \\
\hline OP-T19 & ${ }^{5^{\prime}} \mathrm{GTCCGTATGG}^{3^{\prime}}$ & 4 & 4 & 3.57 & 4.0 \\
\hline OP-T20 & ${ }^{5^{\prime}} \mathrm{GACCAATGCC}^{3^{\prime}}$ & 3 & 1 & 2.68 & 1.0 \\
\hline OP-V09 & 5'TGTACCCGTC ${ }^{3 \prime}$ & 3 & 3 & 2.68 & 3.0 \\
\hline OP-V14 & ${ }^{5^{\prime}} \mathrm{AGATCCCGCC}^{3^{\prime}}$ & 4 & 3 & 3.57 & 3.0 \\
\hline OP-V19 & ${ }^{5^{\prime}}$ GGGTGTGCAG $^{3^{\prime}}$ & 6 & 5 & 5.36 & 5.0 \\
\hline & Total & 112 & 100 & - & - \\
\hline
\end{tabular}

As the primer efficiency depends on the total number of bands amplified by the primer and this could include a number of common (monomorphic) ones (representing conserved sequences among various species, efficiency would not be very informative in identifying species. A more informative parameter in this respect is the primer discriminatory power (Grrundman et al., 1995). Discriminatory value of a primer depends only on the number of polymorphic bands produced by the primer relative to the total number of polymorphic bands produced by all primers. Polymorphic bands are essential in identification in two ways; first in generating patterns of banding that are unique to individual species and second in exhibiting or lacking unique band (s) (marker bands) that distinguish an individual from the rest of the population. Therefore discriminatory power of a primer is more important than its efficiency in determining its DNA fingerprint and two primers with similar efficiencies (e.g. OP-L05 and OP-M14 both with total number of bands of 7 and an efficiency of 6.25 for both of them) gave different powers, 6.0 for OP-L05 to identify two isolates $(1,3)$ only, and 7 for OP-M06 to identify seven out of the nine isolates tested (Tables 4 and 5). However, primers with equal discriminatory values may have different capacities in identifying species (e.g. OP-I02 and OP-L05 both with discriminatory power of 6 but the first primer gave 9 unique patterns of banding and identified all 9 species while the second gave 4 patterns and identified only 2 species $(1,3)$ (Tables 4 and 5) ). Obviously, primer OP-I05 was the best primer in identification as, with just 6 polymorphic bands, it 
distinguished all nine species whether by unique patterns of banding or by the marker bands. Primer OP-M05 did similarly but only with 9 polymorphic bands (Table 5). There were two primers (OP-E20 and OP-T20) that could not distinguish any of the nine species whether by patterns or by marker bands. The remaining markers managed to differentiate various numbers of the species whether by patterns, by marker bands or by both (Table 5).

Table 5: Species identified by the unique patterns of banding and/or by the marker bands of the RAPD data.

\begin{tabular}{|c|c|c|c|c|c|}
\hline \multirow{2}{*}{ Primer } & \multirow{2}{*}{$\begin{array}{l}\text { No. of } \\
\text { bands }\end{array}$} & \multirow{2}{*}{$\begin{array}{l}\text { No. of } \\
\text { polymorphic } \\
\text { bands }\end{array}$} & \multirow{2}{*}{$\begin{array}{l}\text { No. of unique } \\
\text { patterns of } \\
\text { banding }\end{array}$} & \multicolumn{2}{|c|}{ Species identified by } \\
\hline & & & & Unique patterns & $\begin{array}{l}\text { Marker bands: } \\
\text { Fingerprinted }\end{array}$ \\
\hline OP-C05 & 4 & 1 & 2 & $4^{*}$ & $4^{*},(-1.48)$ \\
\hline OP-E20 & 4 & 1 & 2 & None & None \\
\hline OP-H01 & 2 & 2 & 4 & 5 & None \\
\hline OP-I02 & 6 & 6 & 9 & $1,2,3,4,5,6,7,8,9$ & $1,(1.05) ; 2,(-1.12)$ \\
\hline OP-K01 & 8 & 8 & 7 & $1,3,5,8,9$ & $\begin{array}{c}1,(2.1) ; 3,(2.25,1.5) ; 9,(\text { All } \\
\text { bands lacking) }\end{array}$ \\
\hline OP-L05 & 7 & 6 & 4 & 1,3 & $3,(1.66)$ \\
\hline OP-L20 & 9 & 9 & 8 & $1,2,3,4,5,7,9$ & $1,(1.52)$ \\
\hline $\begin{array}{l}\text { OP- } \\
\text { M05 }\end{array}$ & 10 & 10 & 9 & $1,2,3,4,5,6,7,8,9$ & $1,(1.6,-1.52,1.32) ; 6(1.75)$ \\
\hline $\begin{array}{l}\text { OP- } \\
\text { M06 }\end{array}$ & 9 & 9 & 8 & $1,2,3,4,6,7,9$ & $\begin{array}{c}\text { 1,(All bands lacking); 3,(1.9); } \\
6,(2.4)\end{array}$ \\
\hline $\begin{array}{l}\text { OP- } \\
\text { M14 }\end{array}$ & 7 & 7 & 8 & $1,4,5,6,7,8,9$ & $1,(1.23) ; 9,(1.32)$ \\
\hline $\begin{array}{l}\text { OP- } \\
\text { M20 }\end{array}$ & 3 & 3 & 4 & 1 & $1,(-1.82)$ \\
\hline OP-N16 & 6 & 6 & 5 & 1,9 & $1,(1.91)$ \\
\hline OP-P04 & 5 & 5 & 8 & $1,2,3,4,5,6,7$ & None \\
\hline OP-R06 & 3 & 3 & 4 & 1 & $1,(-1.48)$ \\
\hline OP-R12 & 5 & 5 & 8 & $1,2,3,4,5,6,8$ & None \\
\hline OP-R14 & 4 & 3 & 4 & $1,5,8$ & $1,(3.16) ; 5,(2.24) ; 8,(-1.86)$ \\
\hline OP-T19 & 4 & 4 & 5 & $1,2,3,4$ & None \\
\hline OP-T20 & 3 & 1 & 2 & None & None \\
\hline OP-V09 & 3 & 3 & 5 & $1,3,9$ & None \\
\hline OP-V14 & 4 & 3 & 6 & $2,6,9$ & $6,(2.29)$ \\
\hline OP-V19 & 6 & 5 & 8 & $1,3,5,6,7,8,9$ & $3,(1.82) ; 8,(1.29)$ \\
\hline
\end{tabular}

- *, Numbers in these columns refer to the fungal species numbers (Table 1).

- Bracketed values are sizes (kbp) of marker bands .

- - , indicates absence of a common band.

Polymorphic bands or fragments were also useful in deciding the genetic similarity between species and estimating the genetic distances between each pair of species (Nei and Li, 1979). The longest distance was 0.7879 separating between the two species A.radicina and A.raphani, while the closest species to each other were A.state and A.tenuissima with a genetic distance of only 0.1854 (Table 6) the remaining genetic distances were between 
these two limits (Table 6). These distances were used to produce the clustering dendrogram of the nine species (Fig. 2).

In addition to identify the isolates through the production of unique patterns of banding in the various species, the primers also succeeded in fingerprinting most ( 8 of 9 ) of the isolates. Fingerprinting of an isolate is indicated when it shows a specific band or bands (marker bands) which is absent in other isolates when amplified by the same primer. Or vice versa, it is manifested by the absence from the isolate of a band which is common to all isolates treated with same primer. In this respect, all strains but one (strain 7) were fingerprinted by one primer (strains 2,4,5,8), two primers (strain 9), three primers (strain 6), four primer (strain 3) or ten primers (strain 1) (Table 5). Obviously, strain 1 (A. radicina) has the most variable genome among the nine species tested as it showed 12 specific RAPD alleles (specific bands) (Table 5).

Table 6: Matrix of genetic distance between the nine Alternaria species as deduced from their RAPD markers.

\begin{tabular}{|c|c|c|c|c|c|c|c|c|c|}
\hline & 1 & 2 & 3 & 4 & 5 & 6 & 7 & 8 & 9 \\
\hline 1 & 0 & & & & & & & & \\
\hline 2 & 0.6063 & 0 & & & & & & & \\
\hline 3 & $\mathbf{0 . 7 8 9 7}$ & 0.2801 & 0 & & & & & & \\
\hline 4 & 0.7146 & $\mathbf{0 . 1 8 5 4}$ & 0.3747 & 0 & & & & & \\
\hline 5 & 0.5097 & 0.3097 & 0.3534 & 0.3823 & 0 & & & & \\
\hline 6 & 0.6861 & 0.5886 & 0.5672 & 0.7305 & 0.4207 & 0 & & & \\
\hline 7 & 0.6779 & 0.4934 & 0.5050 & 0.6132 & 0.4126 & 0.2272 & 0 & & \\
\hline 8 & 0.7666 & 0.5773 & 0.5534 & 0.7277 & 0.4028 & 0.2349 & 0.2268 & 0 & \\
\hline 9 & 0.6276 & 0.4611 & 0.5566 & 0.5951 & 0.4498 & 0.3406 & 0.2601 & 0.2986 & 0 \\
\hline
\end{tabular}

1-A.rancidina 2- A.state, 3- A.raphani, ,4-A.tenuissima ,5- A.alternata1,6-A.longipes,7A.brassicae,8-A.alternata2,9-A.cheiranthi.

The species clustered in three major groups. The first one included the single species A.radicina (Fig. 2). This result corresponded well with the result obtained by AL-Taee (2007) who used phenotypic characteristics and put this species in a distinct group. Therefore, phenetic features do reflect real genetic specificities as detected by the RAPD analysis . the second cluster included four species; A.state , A. tenuissima , A. raphani and A. alternata1. However, phenotypic classification of AL-Taee, (2007) put A. state and A. tenuissima closely together in a single group while the two species $A$. raphani and $A$. alternata1 were put into a separate group. Comparing sequences of the internal transcribed spacer (ITS) of the ribosomal (rDNA) and the mitochondrial small subunit (mtSSU) 
ribosomal DNA of various Alternaria and related fungal species, Pryor and Gilbertson, (2000) were able to separate the two species A. state and A. tenuissima into a group distinct from the rest of Alternaria species . Result from the RAPD analysis reported in the present work put $A$. state and $A$. tenuissima into a separate group with the least genetic distance (0.1854) between any other pair of the nine Alternaria species tested (Table 6), but still within the same major group comprising the four species A. state, A. tenuissima, A. raphani, and $A$. alternata1 (Fig. 2). Putting these four species, by the RAPD analysis, into a single major cluster might indicate a common sequences into a noncoding DNA in the species and hence phenotypic clustering and RAPD clustering might not correspond.

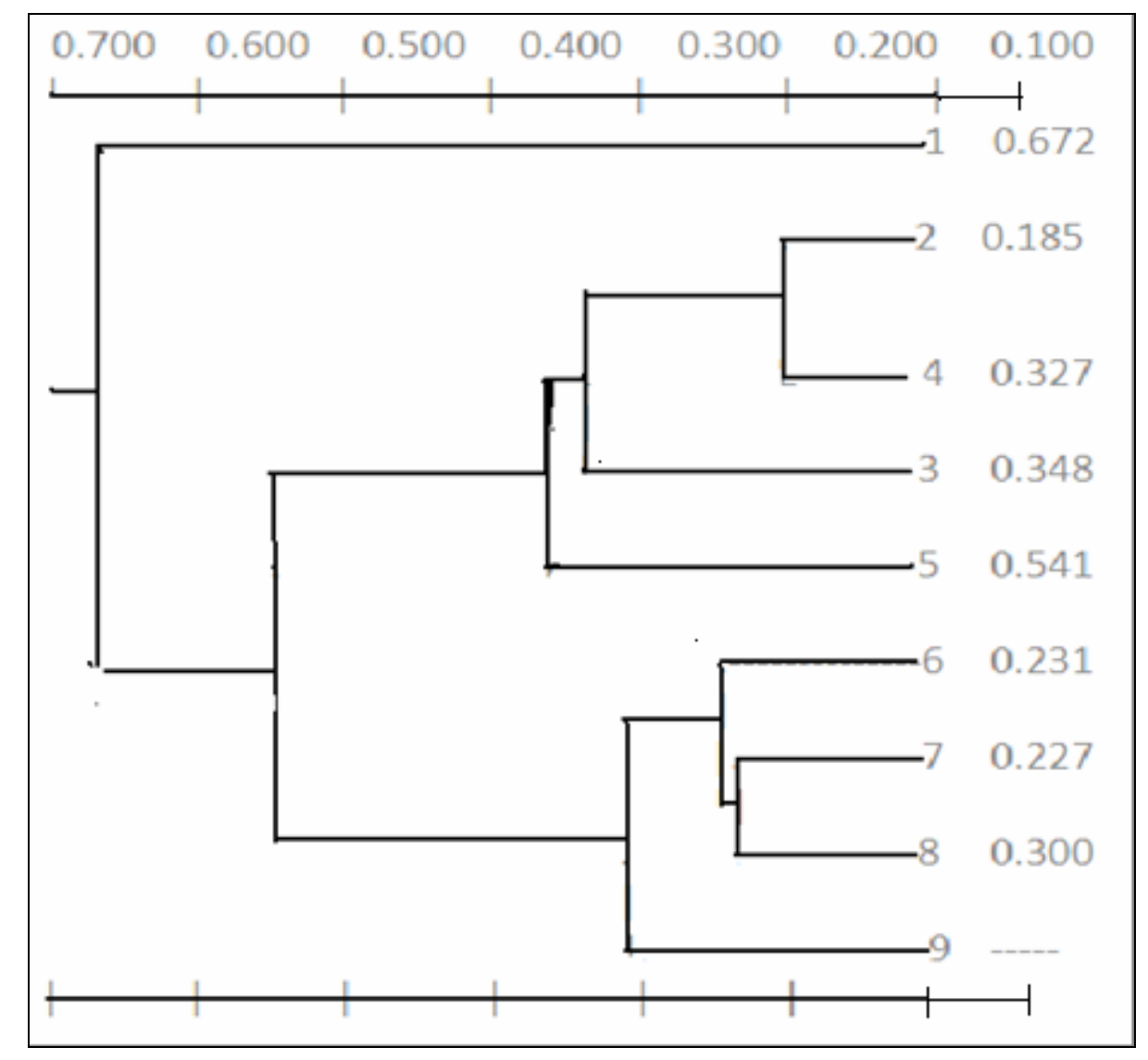

1-A.rancidina, 2- A.state, 3- A.raphani, ,4-A.tenuissima ,5- A.alternata1 ,6-A.longipes,7-A.brassicae,8-A.alternata2,9-A. cheiranthi.

Fig.2. The genetic dendrogram of the nine Alternaria species revealed by their RAPD markers.

The third major cluster comprised four species ; A. alternata2, A. cheiranthi, A. brassicae and $A$. longipes (Fig. 2) with genetic distances ranging between 0.2272 (between A. longipes and A. brassicae ) and 0.3406 (between A. longipes and A. cheiranthi ) (Table 6). Phenotypic classification (AL-Taee, 2007), however, separated these four species into two distinct groups (A .longipes and A. brassicae in one group, and A. alternata2 and cheiranthi in another group ). Again, this RAPD grouping of the four species into a single group as opposed to two groups established by phenotypic criteria might reflect the presence of common sequences of no codding function in the four species, so that they 
could exhibit banding similarity but phenotypic diversity. Furthermore, the RAPD data did not reveal a clear association between the clustering patterns of the species (Fig. 2) and their host distribution (Table 1). The four species of the second cluster had been isolated from four different hosts and similarly the four members of the third cluster had also been isolated from four different crop plants. Moreover, A. state of the second cluster and $A$. longipes of the third cluster shared the same host, Brassica oleracea (Fig. 2 and Table 1). Association between phenotypic characteristics of organisms and patterns resulting from typing these organisms with DNA molecular (RAPD, AFLP ) markers seems to vary . Ozbey et al., (2005) found no association between RAPD fingerprints and serotypes in the bacteria Ornithobacterium rhinotracheale isolated from chicken, for they found different patterns within the same serotype (A) and similar patterns within two (A and B ) serotypes. Lack of association between RAPD pattern and source of isolation have also been reported for the fungus Fusarium sambucinum (Sabir, 2006). Also, cluster analysis did not reveal association between pathotypes and AFLP (Amplified fragment length polymorphism ) markers in the fungus Cochliobolus sativum (Zhong and Steffenson, 2001). However cluster analysis did reveal close association between RAPD patterns and virulence and geographic orgins of the fungus Fusarium oxysparium f. sp vasinfecfum (Assigbetse et al., 1994).

\section{AKNOWLEDGEMENTS}

The authors are deeply indebted to Dr. Warka S. Q. AL-Taee, for providing the species of Alternaria used in the present analysis.

\section{REFERENCES}

Al-aaraji, A. M. (2003). DNA Fingerprinting of fusarium solani (mart.) sacc isolates causing root and stem rot of eggplant by using randomly amplified polymorphic DNA (RAPD). Msc. Thesis, Baghdad University. (Arabic with English Abstract).

Al-Taee, W. S. Q. (2007). Taxonomic study of the leaf- spot disease causing species of the genus alternaria to select a model target for biological control in mosul. Ph. D. thesis. Mosul university, Iraq. (Arabic with English Abstract).

Assigbetse, K. B.; Fernandez, D. ; Doubios, M. P.; Geiger, J. P.(1994). Differentiation of Fusarium oxysporum f. sp. Vasinfectum races on cotton by random amplified polymorphic DNA (RAPD) analysis. Phytopathol.,84, 622 - 626.

Bardakci , F. (2001). Random amplified polymorphic DNA (RAPD) markers. Turk. J. Biol., $25,185-196$.

Botestein, D.; White, R. L.; Skolnick, M. ; Davis, R. W. (1980). Construction of genetic linkage map in man using restriction fragment length polymorphisms . Am. J. Hum. Genet., 32, 314-331.

Caetano -Anolles, G. ; Gresshoff, P. M. (1998). "DNA Markers Protocols , Application and Overviews" . Wiley, New York.

Cao, W.; Scoles, G.; Hucl, P. ; Chibbar, R. N. (1999). The use of RAPD analysis to classify Triticum accessions. Theor. Appl. Genet., 98 , 602-607.

Devos, K. M. ; Gale, M. D. (1992). The use of random amplified polymorphic DNA markers in wheat. Theo. Appl. Genet., 84, 567-572. 
Fristch, P.; Hanson, M. A.; Spore, C. D.; Pack, P. E. ; Riseberg, L. H. (1993). Constancy of RAPD primer amplification strength among distantly related taxa of flowering plants. Plant Mol. Boil. Res., 11, 10-20.

Grundman , H. ; Scheidre, C. ; Hartung, D. ; Daschner, F. D. ; Pitt, T. L. (1995). Descriminatory power of three DNA based typing techniques for p. aeruginosa . $J$. Clin. Microbiol., 33, 528-534.

Karp, A. ; Edwards, K. J. (1997)." DNA markers a global overview. In: G. CaetanoAnolle's and P. M. Gresshoff (eds DNA Markers Protocols, Application and Overviews)". Wiley, New York. pp. 1-13.

Lawrence, H. M. (1964). " Taxonomy of Vascular Plants". Macmillan, New York.

Mullis, K. B.; Faloona, F.; Scharf, S.; Saiki, R. K.; Horn, G.; Erlick, H. A.(1986). Specific enzymatic amplification of DNA in vitro the Polymerase chain reaction. Cold Spring Harbor Sym. Quant. Biol.,51 , 263-273.

Nei , M. ; Li, W. H. (1979). Mathematical model for studying genetic variation in terms of restriction endonucleases . Proc. Natl. Acad. Sci. USA ,76, 5269-5273.

Newton, C. R. ; Graham , A. (1997)." Polymerase Chain Reaction ". Bios , Oxford, U.K.

Ozbey, G.; Ertas, H. B. ; Muz, A. (2005). Random amplified polymorphic DNA (RAPD) analysis of Ornithobacterium rhinotracheale strains isolated from chickens in Turkey. Vet. Med.- Czech, 50 , 526-530.

Pryor, B. M. ; Gilbertson, R. L. (2000). Molecular phylogenetic relationships among Alternaria species and related fungi based upon analysis of nuclear ITS and mtSSU rDNA sequences. Mycol. Res., 104, 1312-1321.

Rohlf, F.J. (1993). "Numerical Taxonomy and Multivariate Analysis System.Version 1.80 Exeter software Setauket". NewYork.

Rafalski, J. A.(1997). "Randomly amplified polymorphic DNA (RAPD) analysis". In: DNA Markers Protocols, Application and Overviews . Wiley, New York. pp.75-83.

Sabir, J. S.(2006). Genotype Identification for some Fusarium sambuciuum stain isolated from wheat in upper Egypt. World J. Agr. Sci., 2 , 06-10 .

Sambrook, J.; Fritch E. F. ; Maniatis, J. (1989) . "Molecular Cloning : A Laboratory Manual". Cold Spring Harbor Laboratory Press, New York.

Simpson, G. G. (1961). "Principles of Animal Taxonomy". Columbia University Press.

Smith, P. M. (1976)." Chemotaxonomy". Arnold, London .

Sneath, P. H. A. ; Sokal, R. R. (1973). "Numerical Taxonomy". Freeman, San Francisco.

Tahir, N. A. R. (2008). Assessment of genetic diversity among wheat varieties in Sulaimanyah using random amplified polymorphic DNA (RAPD) analyses. Jordan J. Biol. Sci.,1 , 159-164.

Welsh, J. ; McClelland, M. (1990). Fingerprinting genomes using PCR with arbitray primers . Nucl. Acids Res., 18 , 7213-7218.

Weigand, F.; Baum, M. ; Udupa , S. (1993). "DNA Molecular Marker Techniques". Technical Manual. No.20. International Center For Agricultural Research in the Dry Area . Aleppo, Syria.

Williams, J. G. ; Kubelic , A. R. ; Livak, K. J. ; Rafalski , J. A. ; Tingey, S. V. (1990). DNA polymorphisms amplified by aribitary primers are useful as genetic markers . Nucl. Acid Res., 18 , 6531-6535. 
Zaid , A. ; Hughes , H. G. ; Porceddu , E. ; Nicholas , F. W. (1999). Glossary of Biotechnology and Genetic Engineering . FAO Research and Tachnology Paper 7. Food And Agriculture Organization of the United Nations. Rome.

Zhong, S. ; Steffenson, B. J. (2001). Virulence and molecular diversity of Cochliobolus sativum. Phytopathol., 91 , 469-475. 